\title{
Epidemiology of lymphoid malignancies: last decade update
}

\author{
Silvana Novelli*, Javier Briones and Jorge Sierra
}

\begin{abstract}
Background: The non-Hodgkin lymphomas are $12^{\text {th }}$ most prevalent cancers in Europe. No recent update in the epidemiology of these lymphomas has been performed in our country. We diagnosed 701 new lymphomas during the period beginning January 1, 2000 and ending December 31, 2009 in our center.

Findings: The most frequent lymphoma was diffuse large B cell lymphoma, followed by follicular lymphoma and then classic Hodgkin's disease. The male:female ratio is 1.2:1. Diagnosis by age showed that non-Hodgkin's lymphoma is by far more frequent in the 61-80 years old patients. On the other hand, classic Hodgkin's lymphoma is more frequent in the 20-40 years old population.
\end{abstract}

Conclusion: Our results are very similar to those published by other centers in Europe and United States

\section{Introduction}

Cancer is one of the leading causes of death worldwide and accounted for 7.6 million deaths (13\% of all deaths) in 2008 according to the World Health Organization. The age-world-standardized incidence rate (per 100000) for non-Hodgkin lymphoma (NHL) and Hodgkin lymphoma (HL) are 6.7 and 2 respectively. The NHL is the $12^{\text {th }}$ most prevalent cancer in Europe (GLOBOCAN 2008).

Lymphoid malignancies compose a variety of different morphologic and clinical syndromes. Many publications affirm that incidence of lymphoid malignancies is increasing despite only a few reports have been performed using at least the 2001 WHO classification (Jaffe et al. 2001).

The later classification was the first to incorporate morphology, immunophenotype, cytogenetic and molecular features, clinical behavior, and some known aspects of etiology and pathogenesis into the definition of each disease subtype.

Even though, the current classification is the 2008 WHO classification where new entities are defined, and solutions for problematic categories are sought, these features do not interfere with a new epidemiological analysis.

The aim of this report is to update the frequencies of lymphoid malignancies in the past 10 years in our center in Barcelona, Spain.

\footnotetext{
* Correspondence: snovelli@santpau.cat

Hematology Service, Hospital de la Santa Creu i Sant Pau, Barcelona, Spain
}

\section{Material and method \\ Materials}

Our analysis considers the frequencies of all lymphoid neoplasms diagnosed during the 10 -year study period beginning January 1, 2000 and ending December 31, 2009.

For each newly identified lymphoid neoplasm case, patient demographic data, including age and sex, and information on the tumor histologic type, primary site, and immunophenotype were collected.

Our Hospital is a university hospital, which has a referral population around 500000 patients. It is considered a highly qualified center in hematologic disorders.

Tissue samples were studied by histological examination of surgical biopsy from an accessible nodal site by the Pathology department. Diagnosis was established based on clinical information and cyto-morphological diagnostic criteria as recommended by the current World Health Organization Classification.

All patients signed consent forms before biopsies were taken and it included the use of their samples for investigation purposes.

\section{Statistical analysis}

Data was analyzed using SPSS for MAC OS version 20.

The statistical methods applied include frequency counts and cross tabulations. 


\section{Findings}

We diagnosed 701 new lymphomas during the period beginning January 1, 2000 and ending December 31, 2009.

The frequency for each year is described in Table 1 . We diagnosed a mean of 74 lymphomas per year. There was not any significant frequency variation between years.

The most frequent lymphoma was diffuse large B cell lymphoma, followed by follicular lymphoma and then classic Hodgkin's disease (Table 2). Inside the diffuse large B cell lymphoma group we included 5 post allogeneic hematopoietic stem cell transplantation lymphoma (EBV-related). None of these patients had previous history of lymphoma and these patients were the only with recent previous chemotherapy administration history. Excluding post transplant lymphoma, EBV positivity was present only in $2 \%$ of the cases. $(1,2 \%$ were older than 60 years old)

\section{Frequencies by sex}

The number of lympholiferative disorders diagnosed in our center between January 2000 and December 2009 was 701, 382 males and 319 females. The male:female ratio is 1.2:1.

Only splenic and nodal marginal cell lymphomas were found to be more frequent in women. This difference was also present in follicular lymphoma but in a minor degree.

\section{Frequencies by age}

Diagnosis by age showed that non-Hodgkin's lymphoma are by far more frequent in the 61-80 years old patients. On the other hand, Classic Hodgkin's lymphoma is more frequent in the 20-40 years old population (Figure 1).

\section{Discussion}

Despite recent advances in new therapeutic chemotherapy regimens for lymphoma, epidemiological studies worldwide are few and almost absent in Spain.

Table 1 Lymphoma frequencies by year of diagnosis

\begin{tabular}{ll}
\hline Year of diagnosis & Frequency \\
\hline 2000 & $78(11.1 \%)$ \\
2001 & $67(9.6 \%)$ \\
2002 & $74(10.6 \%)$ \\
2003 & $85(12.1 \%)$ \\
2004 & $87(12.4 \%)$ \\
2005 & $53(7.6 \%)$ \\
2006 & $30(4.3 \%)$ \\
2007 & $70(10 \%)$ \\
2008 & $83(11.8 \%)$ \\
2009 & $74(10.6 \%)$ \\
Total & 701 \\
\hline
\end{tabular}

Table 2 Lymphoma's frequencies

\begin{tabular}{ll}
\hline Diagnosis & Frequency \\
\hline Diffuse large B cell lymphoma & 241 \\
Chronic Lymphocytic Leukemia/Small Lymphocytic & $(34.4 \%)$ \\
Lymphoma & $37(5.3 \%)$ \\
Mantle Cell Lymphoma & $29(4.1 \%)$ \\
Follicular Lymphoma & 127 \\
Splenic Marginal Zone Lymphoma & $(18.1 \%)$ \\
Nodal Marginal Zone Lymphoma & $16(2.3 \%)$ \\
Extranodal Marginal Zone Lymphoma & $6(0,9 \%)$ \\
Burkitt's Lymphoma & $51(7.3 \%)$ \\
Plasmablastic Lymphoma & $21(3 \%)$ \\
Peripheral T cell lymphoma NOS & $4(0.6 \%)$ \\
Angioimmunoblastic T cell Lymphoma & $32(4.6 \%)$ \\
Hodgkin's Lymphoma - Classic & $2(0.3 \%)$ \\
non-Classic Hodgkin's lymphoma & $65(9.3 \%)$ \\
Mycosis Fungoides - Sesary Syndrome & $6(0.9 \%)$ \\
Cutaneous Anaplastic Large Cell Lymphoma & $32(4.6 \%)$ \\
Primary Mediastinal B Cell Lymphoma & $5(0.7 \%)$ \\
Anaplastic Large Cell Lymphoma, Alk-Negative & $3(0.4 \%)$ \\
Anaplastic Large Cell Lymphoma, Alk-Positive & $5(0.7 \%)$ \\
T/NK Lymphoma & $5(0.7 \%)$ \\
Adult T Cell Lymphoma & $2(0.3 \%)$ \\
MALT & $1(0.1 \%)$ \\
Waldenström macroglobulinemia & $3(0.4 \%)$ \\
Cutaneous B Cell Lymphoma & $3(0.4 \%)$ \\
\hline
\end{tabular}

We considered very important to update the epidemiology of lymphomas in our center with the aim to focus our investigational efforts in the most prevalent type.

Our results are not so different from the other series published if we consider only the frequencies.

The European Cancer Registry-based project on hematologic malignancies (HAEMACARE) (Marcos-Gragera et al. 2011) includes only one Spanish region (Girone) with 1245 patients diagnosed in period of 8 years. If we extrapolate our data, which includes 701 new cases in a 10 year period for a referral population of 500000 habitants, we have a density of 140 new lymphoma cases per 1 million of referral population per year whereas in Girone they have an approximation of 178 new lymphoma cases per 1 million population per year. Comparing the frequencies of our data with the HAEMACARE data we have some differences within the $B$ cell lymphomas. The most frequent $B$ cell lymphoma in the HAEMACARE 


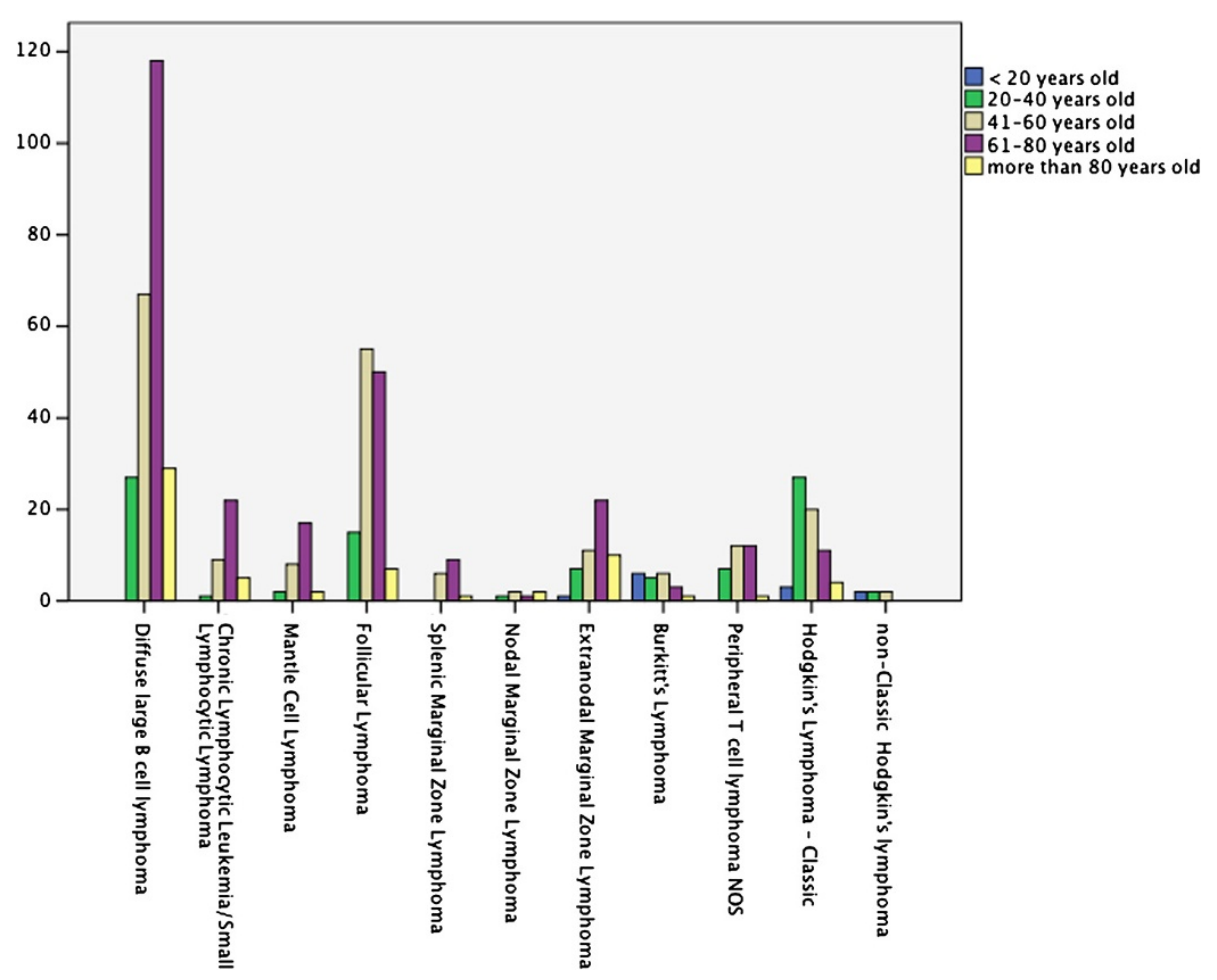

Figure 1 Diagnosis by age.

is CLL/SLL whereas for us is the DLBCL. The cause of this difference may be that in our data we only have included CLL/SLL cases without peripheral expression of the diseases (lymphocytosis). We also have excluded plasmacytoma and multiple myeloma.

There is a very similar work published by University of Benin Teaching Hospital (Nigeria) (Omoti et al. 2012) were they describe the frequencies in a five year interval. The differences between our results and theirs is the male:female ratio which is of 1.2:1 in our data and 1.6:1 in theirs. We also found some differences at the age of diagnosis, which was higher in our report (60-80 years old group). In Benin study the frequencies are higher at 46-59 years old group. Both discrepancies may be related to the "age" of general population and different sex distribution in both continents.

Regarding to the Asiatic reports (Yang et al. 2011) one of them shows higher frequencies in mature $\mathrm{T}$ and $\mathrm{NK}$ cell lymphomas (26\% of total) than in our results in which they account less than $10 \%$ of lymphoid malignancies.

The US report (Morton et al. 2006) does not have differences with our frequencies. We have to say that is a remarkable study because of the quality of the data. They have collected data of 114548 lymphoma cases, included histologic subtypes, molecular data and wide demographic characteristics.

\section{Conclusion}

We conclude that our results are very similar to those reported in other European countries and in the US but are some different from other continents. This suggests one more time that there is an etiologic heterogeneity among lymphomas and support the study of epidemiologic analysis by subtype.

\section{Competing interest}

The authors declare that they have no competing interests.

\section{Authors' contribution}

All authors read and approved the final manuscript.

Received: 24 December 2012 Accepted: 19 February 2013

Published: 26 February 2013

\section{References}

GLOBOCAN (2008) Cancer Incidence, Mortality and Prevalence Worldwide in 2008. Section of Cancer Information (12/8/2012). Wer URL: http://globocan.iarc.fr

Jaffe ES, Harris NL, Stein H, Vardiman JW (eds) (2001) World Health Organization Classification of Tumors. Pathology and Genetics of Tumors of Haematopoietic and Lymphoid Tissues. IARC Press, Lyon, France

Marcos-Gragera R, Allemani C, Tereanu C, De Angelis R, Capocaccia R, Maynadie M, Luminari S, Ferretti S, Johannesen TB, Sankila R, Karjalainen-Lindsberg ML, Simonetti A, Martos MC, Raphaël M, Giraldo P, Sant M, HAEMACARE Working Group (2011) Survival of European patients diagnosed with lymphoid neoplasms in 2000-2002: results of the HAEMACARE project. Haematologica 96(5):720-728, Epub 2011 Feb 17. PubMed PMID: 21330324; PubMed Central PMCID: PMC3084919

Morton LM, Wang SS, Devesa SS, Hartge P, Weisenburger DD, Linet MS (2006) Lymphoma incidence patterns by WHO subtype in the United States, 1992-2001. Blood 107(1):265-276 
Omoti CE, Nwannadi Al, Obieche JC, Olu-Eddo AN (2012) The epidemiological features of lymphoid malignancies in Benin City, Nigeria: a 15 years study. Pan Afr Med J 11:10, Epub 2012 Jan 20. PubMed PMID: 22368753; PubMed Central PMCID: PMC3283024

Yang QP, Zhang WY, Yu JB, Zhao S, Xu H, Wang WY, Bi CF, Zuo Z, Wang XQ, Huang J, Dai L, Liu WP (2011) Subtype distribution of lymphomas in Southwest China: analysis of 6,382 cases using WHO classification in a single institution. Diagn Pathol 6:77

doi:10.1186/2193-1801-2-70

Cite this article as: Novelli et al:: Epidemiology of lymphoid malignancies: last decade update. SpringerPlus 2013 2:70.

Submit your manuscript to a SpringerOpen ${ }^{\circ}$ journal and benefit from:

- Convenient online submission

- Rigorous peer review

- Immediate publication on acceptance

- Open access: articles freely available online

- High visibility within the field

- Retaining the copyright to your article

Submit your next manuscript at $\gg$ springeropen.com 